\title{
Local government responses for COVID-19 management in the Philippines
}

Dylan Antonio S. Talabis ${ }^{1,2^{*}}$, Ariel L. Babierra ${ }^{1,2}$, Christian Alvin H. Buhat ${ }^{1,2}$, Destiny S. Lutero ${ }^{1,2}$, Kemuel M. Quindala III,2 and Jomar F. Rabajante ${ }^{1,2,3}$

\begin{abstract}
Background: Responses of subnational government units are crucial in the containment of the spread of pathogens in a country. To mitigate the impact of the COVID-19 pandemic, the Philippine national government through its Inter-Agency Task Force on Emerging Infectious Diseases outlined different quarantine measures wherein each level has a corresponding degree of rigidity from keeping only the essential businesses open to allowing all establishments to operate at a certain capacity. Other measures also involve prohibiting individuals at a certain age bracket from going outside of their homes. The local government units (LGUs)-municipalities and provinces-can adopt any of these measures depending on the extent of the pandemic in their locality. The purpose is to keep the number of infections and mortality at bay while minimizing the economic impact of the pandemic. Some LGUs have demonstrated a remarkable response to the COVID-19 pandemic. The purpose of this study is to identify notable non-pharmaceutical interventions of these outlying LGUs in the country using quantitative methods.

Methods: Data were taken from public databases such as Philippine Department of Health, Philippine Statistics Authority Census, and Google Community Mobility Reports. These are normalized using Z-transform. For each locality, infection and mortality data (dataset $Y$ ) were compared to the economic, health, and demographic data (dataset $X$ ) using Euclidean metric $d=(x-y)^{2}$, where $x \in X$ and $y \in Y$. If a data pair $(x, y)$ exceeds, by two standard deviations, the mean of the Euclidean metric values between the sets $X$ and $Y$, the pair is assumed to be a 'good' outlier.
\end{abstract}

Results: Our results showed that cluster of cities and provinces in Central Luzon (Region III), CALABARZON (Region IVA), the National Capital Region (NCR), and Central Visayas (Region VII) are the 'good' outliers with respect to factors such as working population, population density, ICU beds, doctors on quarantine, number of frontliners and gross regional domestic product. Among metropolitan cities, Davao was a 'good' outlier with respect to demographic factors.

Conclusions: Strict border control, early implementation of lockdowns, establishment of quarantine facilities, effective communication to the public, and monitoring efforts were the defining factors that helped these LGUs curtail the harm that was brought by the pandemic. If these policies are to be standardized, it would help any country's preparedness for future health emergencies.

Keywords: COVID-19, Local government, Policies, Outlier, Quantitative methods

${ }^{*}$ Correspondence: dstalabis1@up.edu.ph

${ }^{1}$ Institute of Mathematical Sciences and Physics, University of the Philippines Los Baños, Laguna, Philippines

${ }^{2}$ University of the Philippines Resilience Institute, University of the Philippines,

Quezon City, Philippines

Full list of author information is available at the end of the article

(c) The Author(s). 2021 Open Access This article is licensed under a Creative Commons Attribution 4.0 International License, which permits use, sharing, adaptation, distribution and reproduction in any medium or format, as long as you give appropriate credit to the original author(s) and the source, provide a link to the Creative Commons licence, and indicate if changes were made. The images or other third party material in this article are included in the article's Creative Commons licence, unless indicated otherwise in a credit line to the material. If material is not included in the article's Creative Commons licence and your intended use is not permitted by statutory regulation or exceeds the permitted use, you will need to obtain permission directly from the copyright holder. To view a copy of this licence, visit http://creativecommons.org/licenses/by/4.0/. The Creative Commons Public Domain Dedication waiver (http://creativecommons.org/publicdomain/zero/1.0/) applies to the data made available in this article, unless otherwise stated in a credit line to the data. 


\section{Introduction}

Since the emergence of the COVID-19 pandemic, the number of cases have already reached 82 million worldwide at the end of 2020. In the Philippines, the number of cases exceeded 473,000. As countries around the world face the continuing threat of the COVID19 pandemic, national governments and health ministries formulate, implement and revise health policies and standards based on recommendations by world health organization (WHO), experiences of other countries, and on-the-ground experiences. Early health measures were primarily aimed at preventing and reducing transmission in populations at risk. These measures differ in scale and speed among countries, as some countries have more resources and are more prepared in terms of healthcare capacity and availability of stringent policies $[1,2]$.

During the first months of the pandemic, several countries struggled to find tolerable, if not the most effective, measures to 'flatten' the COVID-19 epidemic curve so that health facilities will not be overwhelmed [3, 4]. In responding to the threat of the pandemic, public health policies included epidemiological and socio-economic factors. The success or failure of these policies exposed the strengths or weaknesses of governments as well as the range of inequalities in the society $[5,6]$.

As national governments implemented large-scale 'blanket' policies to control the pandemic, local government units (LGUs) have to consider granular policies as well as real-time interventions to address differences in the local COVID-19 transmission dynamics due to heterogeneity and diversity in communities. Some policies in place, such as voluntary physical distancing, wearing of face masks and face shields, mass testing, and school closures, could be effective in one locality but not in another [7-9]. Subnational governments like LGUs are confronted with a health crisis that have economic, social and fiscal impact. While urban areas have been hot spots of the COVID-19 pandemic, there are health facilities that are already well in placed as compared to less developed and deprived rural communities [10]. The importance of local narratives in addressing subnational concerns are apparent from published experiences in the United States [11], China [12, 13], and India [14].

In the Philippines, the Inter-Agency Task Force on Emerging Infectious Diseases (IATF) was convened by the national government in January 2020 to monitor a viral outbreak in Wuhan, China. The first case of local transmission of COVID-19 was confirmed on March 7, 2020. Following this, on March 8, the entire country was placed under a State of Public Health Emergency. By March 25, the IATF released a National Action Plan to control the spread of COVID-19. A community quarantine was initially put in place for the national capital region (NCR) starting March 13, 2020 and it

Table 1 Epidemiological, economic and demographic factors considered in the study

\begin{tabular}{|c|c|}
\hline Factor & Definition \\
\hline \multirow[t]{2}{*}{ COVID-19 cases } & $\begin{array}{l}\text { Cumulative COVID-19 cases in the Philip- } \\
\text { pines (as of } 10 \text { November 2020) }\end{array}$ \\
\hline & from the DOH Data Drop [19] \\
\hline \multirow[t]{2}{*}{ COVID-19 deaths } & $\begin{array}{l}\text { Cumulative COVID-19 deaths in the Philip- } \\
\text { pines (as of } 10 \text { November 2020) }\end{array}$ \\
\hline & from the DOH Data Drop [19] \\
\hline \multirow[t]{2}{*}{ Population } & $\begin{array}{l}\text { Forecasted } 2020 \text { locality population size } \\
\text { based }\end{array}$ \\
\hline & $\begin{array}{l}\text { from the } 2015 \text { Philippine Statistics Authority } \\
\text { Census [20] }\end{array}$ \\
\hline
\end{tabular}

Population Density

Working Population

Senior Population

Mobility

Doctors on Quarantine

Frontliners

No. of ICU Beds
Forecasted 2020 locality population density based

from the 2015 Philippine Statistics Authority Census [20]

Forecasted 2020 locality working population size ( 21 - 49 yrs old)

based from the 2015 Philippine Statistics Authority Census [20]

Forecasted 2020 locality senior population size (70+ yrs old)

based from the 2015 Philippine Statistics Authority Census [20]

Percentage change in activity at each location category

compared to that on baseline days before the advent of COVID-19

(a 5-week period running from 3 January 2020 to 6 February 2020).

We consider retail and recreation, grocery and pharmacy, parks,

transit stations, workplaces and residential areas [21].

Cumulative number of doctors in quarantine (as of 10 November 2020)

at home or in a facility due to COVID-19 exposure

(close contact, suspect, probable, confirmed) [19].

Cumulative number of nurses in quarantine (as of 10 November 2020)

at home or in a facility due to COVID-19 exposure

(close contact, suspect, probable, confirmed) [19].

Cumulative number of other frontliners currently in quarantine

(as of 10 November 2020) at home or in a facility due to COVID-19

exposure (close contact, suspect, probable, confirmed) [19].

Total number of ICU Beds (as of 10 November 2020) [19]. 
Table 1 Epidemiological, economic and societal factors considered in the study (Continued)

\begin{tabular}{|c|c|}
\hline Factor & Definition \\
\hline Employment & $\begin{array}{l}\text { Employment Rate (as of } 10 \text { November 2020) } \\
\text { [22]. }\end{array}$ \\
\hline \multirow[t]{2}{*}{ Mean Hours Worked } & $\begin{array}{l}\text { The average work hours of an employee in a } \\
\text { week }\end{array}$ \\
\hline & (on 10 November 2020) [22]. \\
\hline GRDP & $\begin{array}{l}\text { Gross Regional Domestic Product (as of } 10 \\
\text { November 2020) [23] }\end{array}$ \\
\hline
\end{tabular}

was expanded to the whole island of Luzon by March 17. The initial quarantine was extended up to April 30 $[5,15]$. Several quarantine protocols were then implemented based on evaluation of IATF:

- Community Quarantine (CQ) refers to restrictions in mobility between quarantined areas.

- In Enhanced Community Quarantine (ECQ), strict home quarantine is implemented and movement of residents is limited to access essential goods and services. Public transportation is suspended. Only economic activities related to essential and utility services are allowed. There is heightened presence of uniformed personnel to enforce community quarantine protocols.

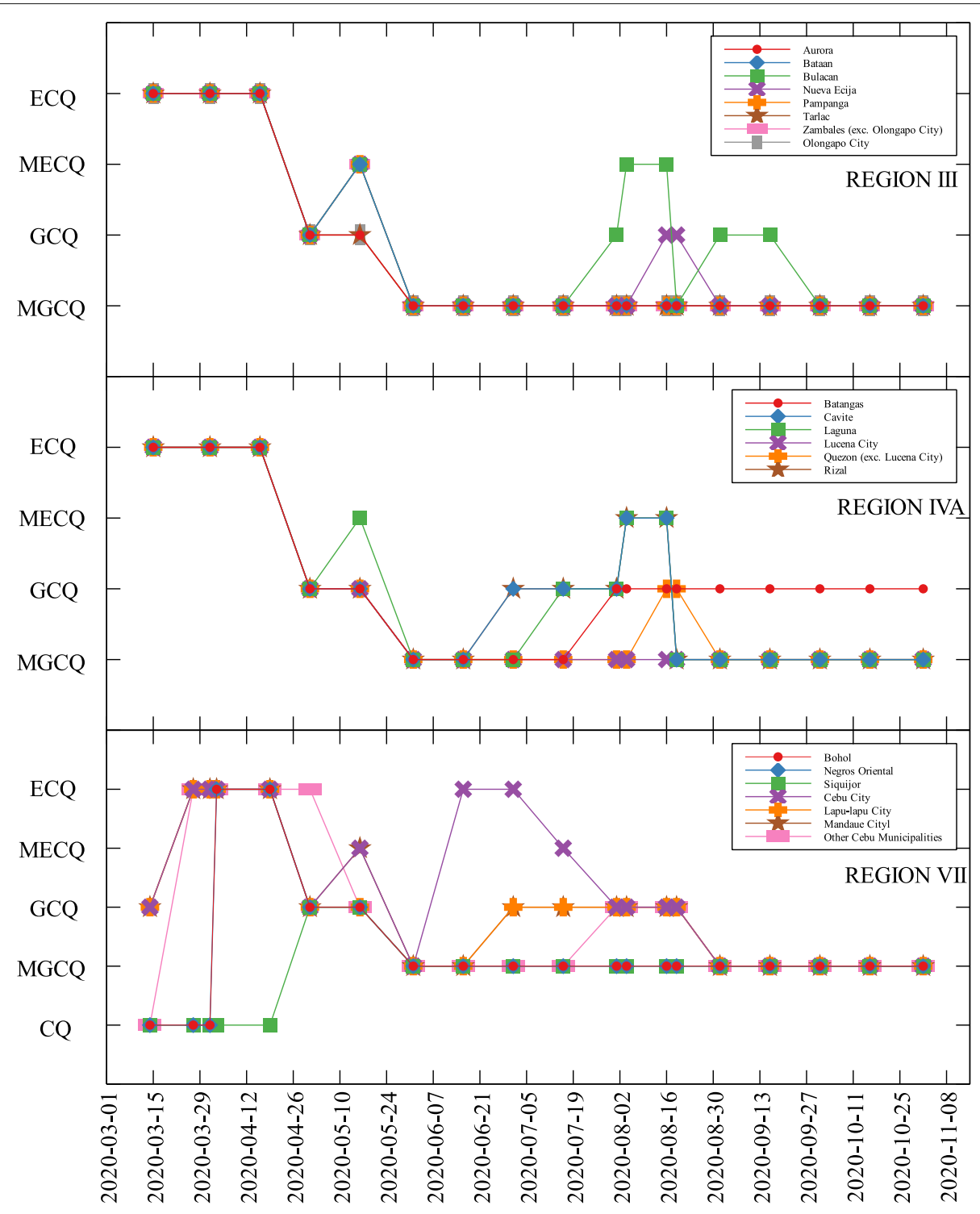

Fig. 1 COVID-19 community quarantines in Regions III, IVA and VII 
Table 2 Correlation table for NCR data

\begin{tabular}{lll}
\hline & Covid cases & Covid death \\
\hline Population & 0.970 & 0.945 \\
Population Density & 0.358 & 0.411 \\
Working Population & 0.969 & 0.926 \\
Senior Population & 0.970 & 0.945 \\
No. of ICU Beds & 0.958 & 0.933 \\
\hline
\end{tabular}

- Modified Enhanced Community Quarantine (MECQ) is implemented as a transition phase between ECQ and GCQ. Strict home quarantine and suspension of public transportation are still in place. Mobility restrictions are relaxed for work-related activities. Government offices operates under a skeleton workforce. Manufacturing facilities are allowed to operate with up to $50 \%$ of the workforce. Transportation services are only allowed for essential goods and services.

- In General Community Quarantine (GCQ), individuals from less susceptible age groups and without health risks are allowed to move within quarantined zones. Public transportation can operate at reduced vehicle capacity observing physical distancing. Government offices may be at full work capacity or under alternative work arrangements. Up to $50 \%$ of the workforce in industries (except for leisure and amusement) are allowed to work.

- Modified General Community Quarantine (MGCQ) refers to the transition phase between GCQ and the New Normal. All persons are allowed outside their residences. Socio-economic activities are allowed with minimum public health standard.

LGUs are tasked to adopt, coordinate, and implement guidelines concerning COVID-19 in accordance with provincial and local quarantine protocols released by the national government [16].

Table 3 Correlation table for metropolitan data

\begin{tabular}{lll}
\hline & Covid cases & Covid death \\
\hline Population & 0.865 & 0.765 \\
Population Density & 0.603 & 0.437 \\
Working Population & 0.998 & 0.981 \\
Senior Population & 0.993 & 0.990 \\
Mobility (Retail and Recreation) & -0.258 & -0.267 \\
Mobility (Grocery and Pharmacy) & 0.137 & 0.112 \\
Mobility (Parks) & -0.149 & -0.136 \\
Mobility (Transit Stations) & -0.533 & -0.591 \\
Mobility (Workplaces) & -0.499 & -0.575 \\
Mobility (Residential) & 0.119 & 0.223
\end{tabular}

Table 4 Correlation table for provincial data

\begin{tabular}{lll}
\hline & Covid cases & Covid death \\
\hline Population & 0.851 & 0.697 \\
Population Density & 0.828 & 0.446 \\
Working Population & 0.874 & 0.803 \\
Senior Population & 0.737 & 0.728 \\
No. of ICU Beds & 0.666 & 0.636 \\
\hline
\end{tabular}

In this study, we identified economic and demographic factors that are correlated with epidemiological metrics related to COVID-19, specifically to the number of infected cases and number of deaths [17, 18]. At the regional, provincial, and city levels, we investigated the localities that differ with the other localities, and determined the possible reasons why they are outliers compared to the average practices of the others.

\section{Methods}

We categorized the data into economic, health, and demographic components (See Table 1). In the economic setting, we considered the number of people employed and the number of work hours. The number of health facilities provides an insight into the health system of a locality. Population and population density, as well as age distribution and mobility, were used as the demographic indicators. The data (as of November 10, 2020) from these seven factors were analyzed and compared to the number of deaths and cumulative cases in cities, provinces or regions in the Philippines to determine the outlier.

The Philippine government's administrative structure and the availability of the data affected its range for each factor. Regional data were obtained for the economic component. For the health and demographic components, data from cities and provinces were retrieved from the sources. Due to the NCR exhibiting the highest figures in all key components, an investigation was conducted to identify an outlier among its cities. The $z$-transform

$$
z=\frac{x-\mu}{\sigma}
$$

where $x$ is the actual data, $\mu$ is the mean and $\sigma$ is the standard deviation were applied to normalize the dataset. Two sets of normalized data $X$ and $Y$ were compared by assigning to each pair $(x, y)$, where $x \in X$ and $y \in Y$, its Euclidean metric $d$ given by $d=(x-y)^{2}$. Here, the $Y$ 's are the number of COVID-19 cases and deaths, and X's are the other demographic indicators. Since $95 \%$ of the data fall within two standard deviations from the mean, this will be the threshold in determining an outlier. This means that if a data pair $(x, y)$ exceeds, by two standard deviations, the mean of the Euclidean metric values between the sets $X$ and $Y$, the pair is assumed to be an outlier. 


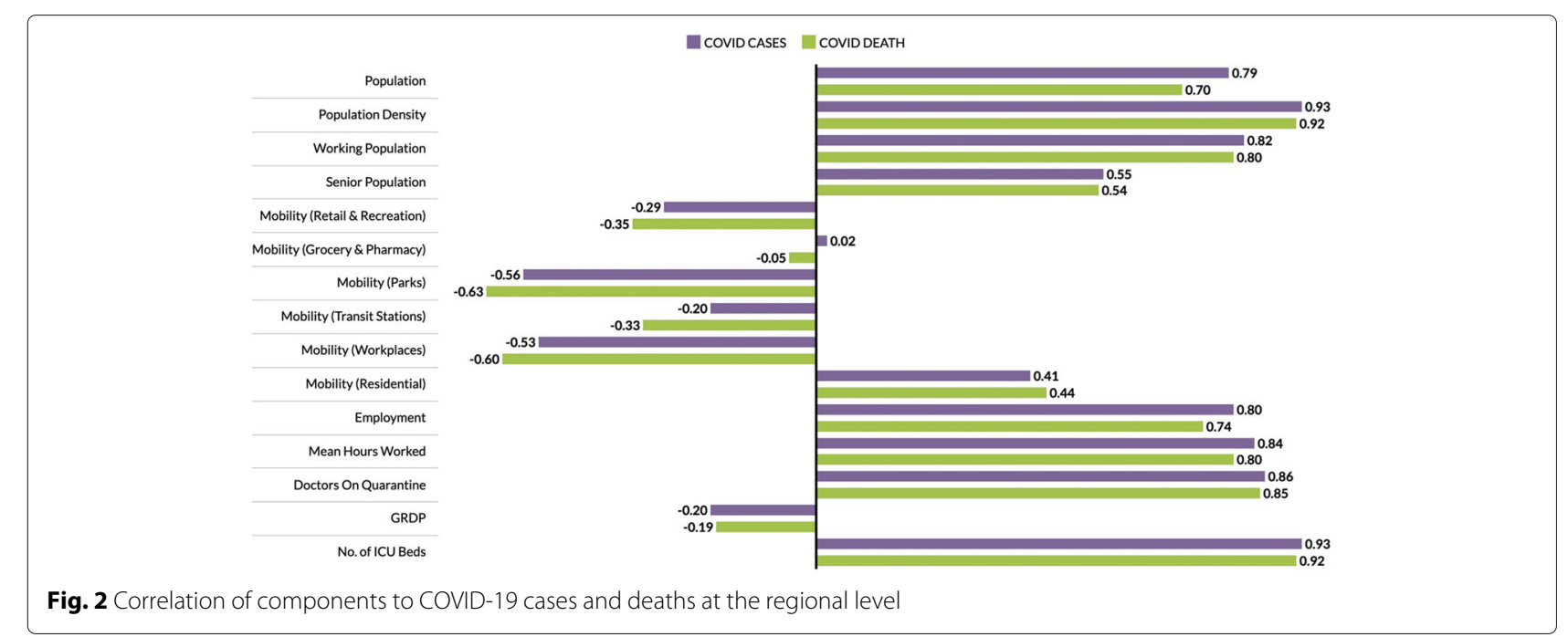

To identify a good outlier, a bias computation was performed. In this procedure, $Y$ represents the normalized data set for the number of deaths or the number of cases while $X$ represents the normalized data set for every factor that were considered in this study. The bias is computed using the metric

$$
(x-y) \times 100
$$

for all $x$ in $X$ and $y$ in $Y$. To categorize a city, province, or region as a good outlier, the bias corresponding to this locality must exceed two standard deviations from the mean of all the bias computations between the sets $X$ and $Y$.

\section{Results and discussion}

The data used were the reported COVID-19 cases and deaths in the Philippines as of November 10, 2020 which is 240 days since community lockdowns were implemented in the country. Figure 1 shows the different lockdowns implemented per province since March 15. It can be seen that ECQ was implemented in Luzon and major cities in the country in the first few weeks since March 15, and slowly eased into either GCQ or MGCQ as time progressed. By August, the most stringent lockdown was MECQ in the National Capital Region (NCR) and some nearby provinces. Places under MECQ on September were Iloilo City, Bacolod City, and Lanao del Sur, with the last province as the lone community to be placed under MECQ the month after. By November 1, 2020, communities were either placed under GCQ or MGCQ.

\section{Comparison of economic, health, and demographic components and COVID-19 parameters}

The economic, health and demographic components were compared to COVID-19 cases and deaths. These comparisons were done for different community levels (regional, provincial, city/metropolitan) (See Tables 2, 3, and 4). Figure 2 summarizes the correlation of components to COVID-19 cases and deaths at the regional level. In all components, correlations with other parameters to both COVID-19 cases and deaths are close. Every component except Residential Mobility and GRDP have slightly higher correlation coefficient for COVID-19 cases as compared to COVID-19 deaths.

Among the components, the number of ICU beds component has the highest correlation with COVID-19 parameters. This makes sense as this is one of the firstdegree measures of COVID-19 transmission. Population density comes in second, followed by mean hours worked and working population, which are all related to how developed the region is economy-wise. Regions having larger population density also have a huge working population and longer working hours [24]. Thus, having a huge population density implies high chance of having contact with each other $[25,26]$. Another component with high correlation to the cases and deaths is the number of doctors on quarantine, which can be looked at two ways; (i) huge infection rate in the region which is the reason the doctors got exposed or are on quarantine, and (ii) lots of doctors on quarantine which resulted to less frontliners taking care of the infected individuals. All definitions of mobility and the GDP are not strongly correlated to any of the COVID-19 measures.

\section{Outliers}

In each data set, outliers were identified depending on their distance from the mean. For simplicity, we denote components that are compared with COVID-19 cases by (C) and with COVID-19 deaths by (D). The summary 


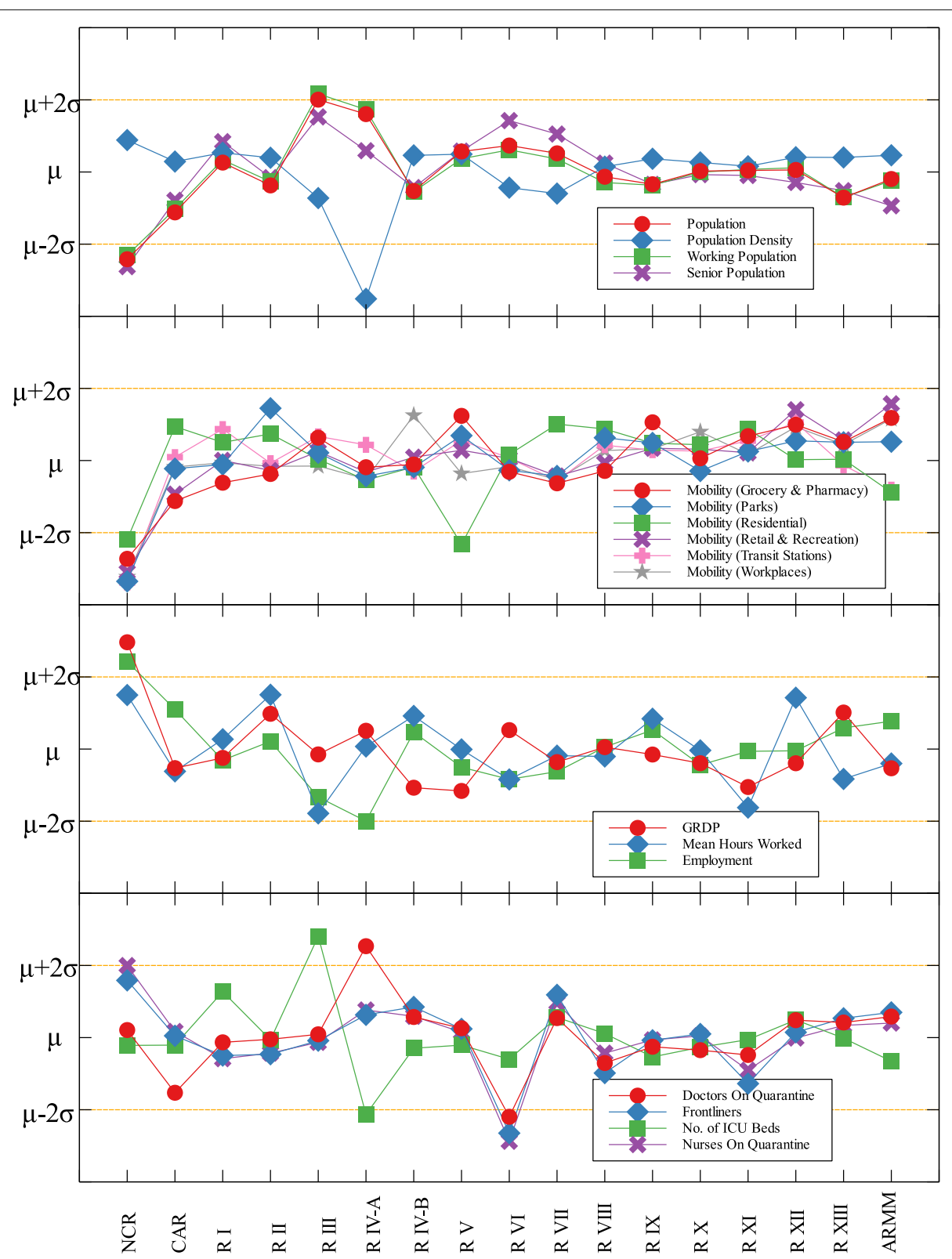

Fig. 3 Outliers among regions in the Philippines with respect to COVID-19 cases

of outliers among regions in the Philippines is shown in Figs. 3 and 4. Data is classified according to groups of component. In each outlier region, non-pharmaceutical interventions (NPI) implemented and their timing are identified.

Region III is an outlier in terms of working population (C) and the number of ICU beds (C) (see Fig. 5 and Table 5). This means that considering the working population of the region, the number of COVID19 infections are better than that of other regions. Same goes with the number of ICU beds in relation to COVID-19 deaths. Region III is comprised of Aurora,
Bataan, Nueva Ecija, Pampanga, Tarlac, Zambales, and Bulacan. This good performance might be attributed to their performance especially on their programs against COVID-19. As early as March 2020, the region had been under a community lockdown together with other regions in Luzon. Being the closest to NCR, Bulacan has been the most likely to have high number of COVID19 cases in the region. But the province responded by opening infection control centers which offer free healthcare, meals, and rooms for moderate-severe COVID-19 patients [27]. They have also implemented strict monitoring of entry-exit borders, organization of provincial 


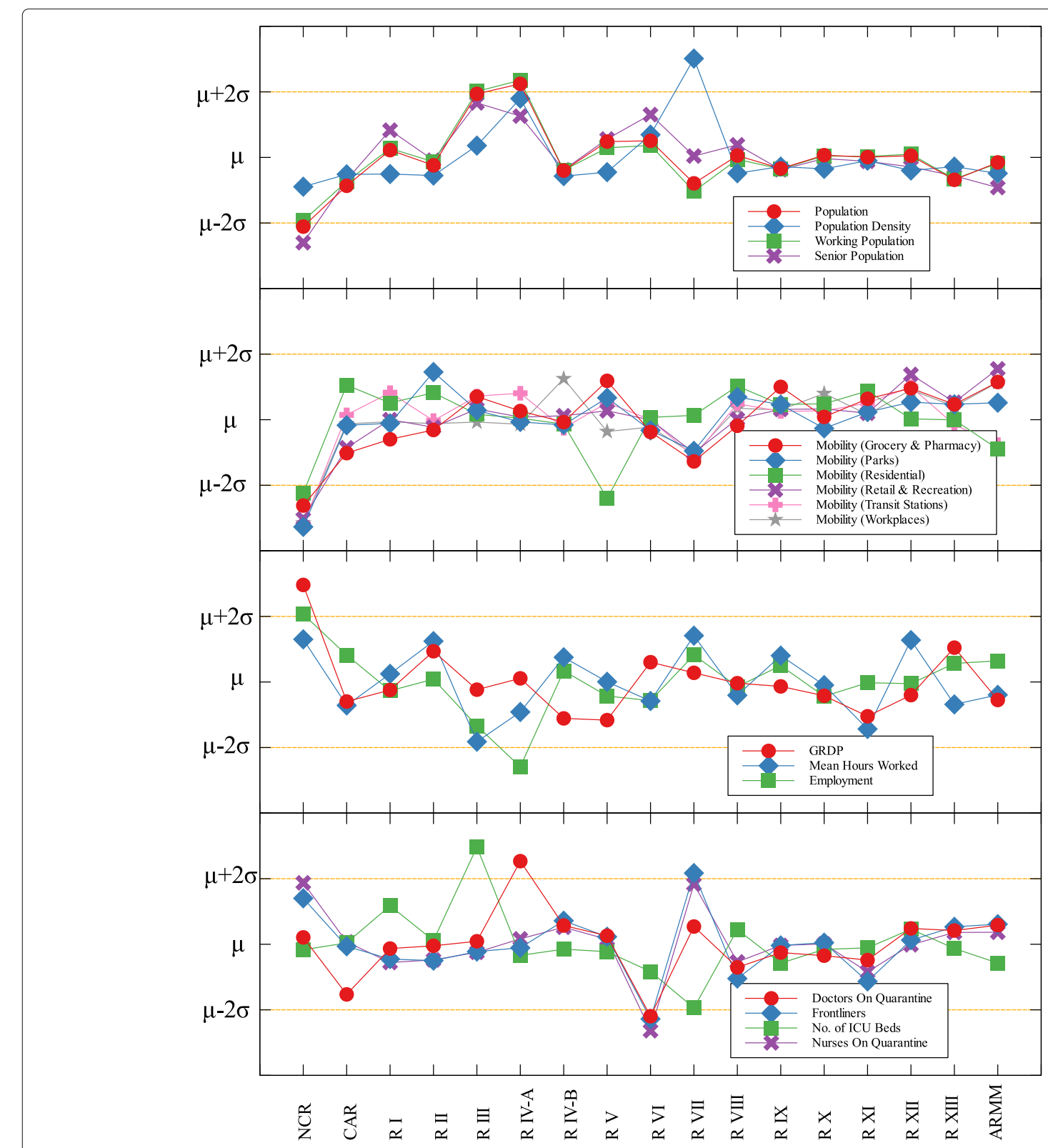

Fig. 4 Outliers among regions in the Philippines with respect to COVID-19 deaths

task force and incident command center, establishment of provincial quarantine facilities for returning overseas Filipino workers, mandated municipal quarantine facilities for asymptomatic cases, and mass testing, among others [27]. Most of which have been proven effective in reducing the number of COVID-19 cases and deaths [28].

Region IV-A is an outlier in terms of population and working population (D) and doctors on quarantine (D) (see Fig. 5 and Table 5). Considering their population and working population, the COVID-19 death statistics show better results compared to other regions. Same goes with the number of doctors in the region which are in quarantine in relation to the reported COVID-19 deaths. This shows that the region is doing well in terms of decreasing the COVID-19 fatalities compared to other regions in terms of populations and doctors on quarantine. Region IV-A is comprised of Batangas, Cavite, Laguna, Quezon, and Rizal. Same with Region III, they have been under the community lockdown since March of last year. Provinces of the region such as Rizal have been proactive in responding to the epidemic as they have already suspended classes and distributed face masks even before the nationwide lockdown [29]. Despite being hit by natural calamities, the region still continue ramping up the response to the 


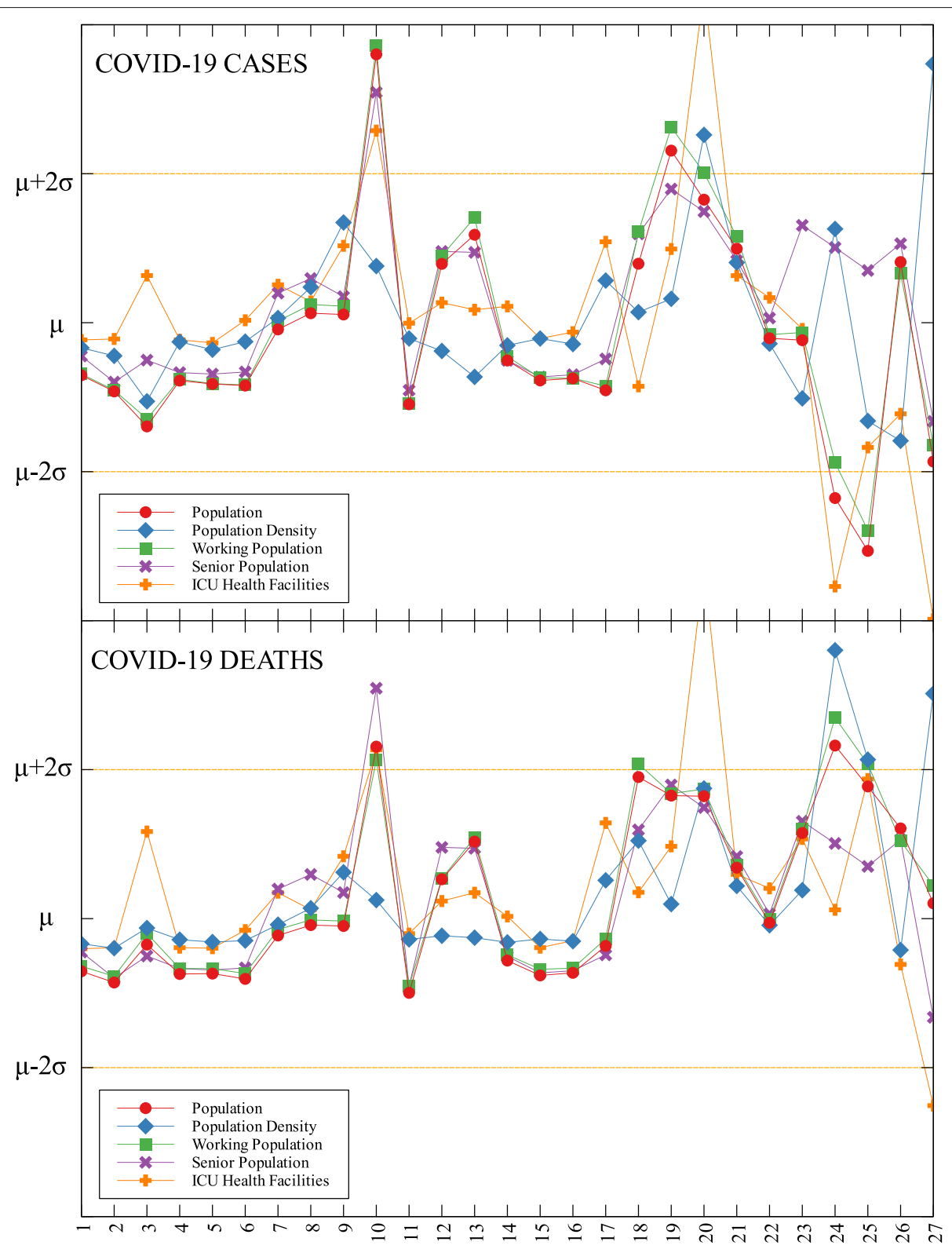

Fig. 5 Outliers among the provinces in Luzon with respect to COVID-19 cases and deaths

pandemic through cash assistance, first aid kits, and spreading awareness [30].

An interesting result is that NCR, the center of the country and the most densely populated, is a good outlier in terms of GRDP (C) and GRDP (D). Cities in the region launched various programs in order to combat the disease. They have launched mass testings with Quezon City, Taguig City, and Caloocan City starting as early as April 2020. Pasig City started an on-the-go market called Jeepalengke. Navotas, Malabon, and Caloocan recorded the lowest attack rate of the virus. Caloocan city had good strategies for zoning, isolation and even in finding ways to be more effective and efficient. Other programs also include color-coded quarantine pass, and quarantine bands. It is also possible that NCR may just have a very high GRDP compared to other regions. A breakdown of the outliers within NCR can be seen in Fig. 8.

Region VII is also an outlier in terms of population density (D) and frontliners (D) (see Fig. 6 and Table 5). This means that given the population density and the number of frontliners in the region, their COVID-related deaths in the region is better than the rest of the country. This region consists of four provinces (Cebu, Bohol, Negros Oriental, and Siquijor) and three highly urbanized cities (Cebu City, Lapu-Lapu City, and Mandaue City), referred to as metropolitan Cebu. This significant decline 
Table 5 Labels for Figs. 5, 6 and 7

\begin{tabular}{|c|c|c|c|c|c|}
\hline Label & Province & Label & Province & Label & Province \\
\hline 1 & Abra & 29 & Occidental Mindoro & 57 & Zamboanga City \\
\hline 2 & Apayao & 30 & Oriental Mindoro & 58 & Zamboanga Sibugay \\
\hline 3 & Benguet & 31 & Palawan & 59 & Bukidnon \\
\hline 4 & Ifugao & 32 & Romblon & 60 & Camiguin \\
\hline 5 & Kalinga & 33 & Albay & 61 & Lanao del Norte \\
\hline 6 & Mountain Province & 34 & Camarines Norte & 62 & Misamis Occidental \\
\hline 7 & Ilocos Norte & 35 & Camarines Sur & 63 & Misamis Oriental \\
\hline 8 & Ilocos Sur & 36 & Catanduanes & 64 & Compostela Valley \\
\hline 9 & La Union & 37 & Masbate & 65 & Davao del Norte \\
\hline 10 & Pangasinan & 38 & Sorsogon & 66 & Davao del Sur \\
\hline 11 & Batanes & 39 & Aklan & 67 & Davao Occidental \\
\hline 12 & Cagayan & 40 & Antique & 68 & Davao Oriental \\
\hline 13 & Isabela & 41 & Capiz & 69 & Cotabato (North Cotabato) \\
\hline 14 & Nueva Vizcaya & 42 & Guimaras & 70 & Sarangani \\
\hline 15 & Quirino & 43 & Iloilo & 71 & South Cotabato \\
\hline 16 & Aurora & 44 & Negros Occidental & 72 & Sultan Kudarat \\
\hline 17 & Bataan & 45 & Bohol & 73 & Agusan del Norte \\
\hline 18 & Bulacan & 46 & Cebu & 74 & Agusan del Sur \\
\hline 19 & Nueva Ecija & 47 & Negros Oriental & 75 & Dinagat Islands \\
\hline 20 & Pampanga & 48 & Siquijor & 76 & Surigao del Norte \\
\hline 21 & Tarlac & 49 & Biliran & 77 & Surigao del Sur \\
\hline 22 & Zambales & 50 & Eastern Samar & 78 & Basilan \\
\hline 23 & Batangas & 51 & Leyte & 79 & Lanao del Sur \\
\hline 24 & Cavite & 52 & Northern Samar & 80 & Maguindanao \\
\hline 25 & Laguna & 53 & Samar (Western Samar) & 81 & Sulu \\
\hline 26 & Quezon & 54 & Southern Leyte & 82 & Tawi-Tawi \\
\hline 27 & Rizal & 55 & Zamboanga del Norte & & \\
\hline 28 & Marinduque & 56 & Zamboanga del Sur & & \\
\hline
\end{tabular}

may be explained by how the local government responded after they were placed in stricter community quarantine measures despite the rest of the country easing in to more lenient measures. Due to the longer and stricter quarantine in Cebu, the lockdown had a greater impact here than in other areas where restrictions were eased earlier [31]. Dumaguete was one of the destinations of the first COVID case in the Philippines [32], their local government was able to keep infections at bay early on. Siquijor was also COVID-19-free for 6 months [33]. The compounded efforts of the different provinces in the region can account for the region being identified as an outlier.

Among the metropolitan cities, Davao came out as a good outlier in terms of population $(C)$ and working population (C) (see Figs. 7, 9, and Table 5). This result may be attributed to their early campaign on consistent communication of COVID-19-related concerns to the public [34]. They were also able to set up transportation for essential workers early on [35].

\section{Conclusions}

This study identified outliers in each data group and determined the NPIs implemented in the locality. Economic, health and demographic components were used to identify these outliers. For the regional data, three regions in Luzon and one in Visayas were identified as outliers. Apart from the minimum IATF recommended NPIs, various NPIs were implemented by different regions in containing the spread of COVID-19 in their areas. Some of these NPIs were also implemented in other localities yet these other localities did not come out as outliers. This means that one practice cannot be the sole explanation in determining an outlier. The compounding effects of practices and their timing of implementation are seen to have influenced the results. A deeper analysis of daily data for different trends in the epidemic curve is considered for future research.

\section{Correlation tables, outliers and community quarantine timeline}




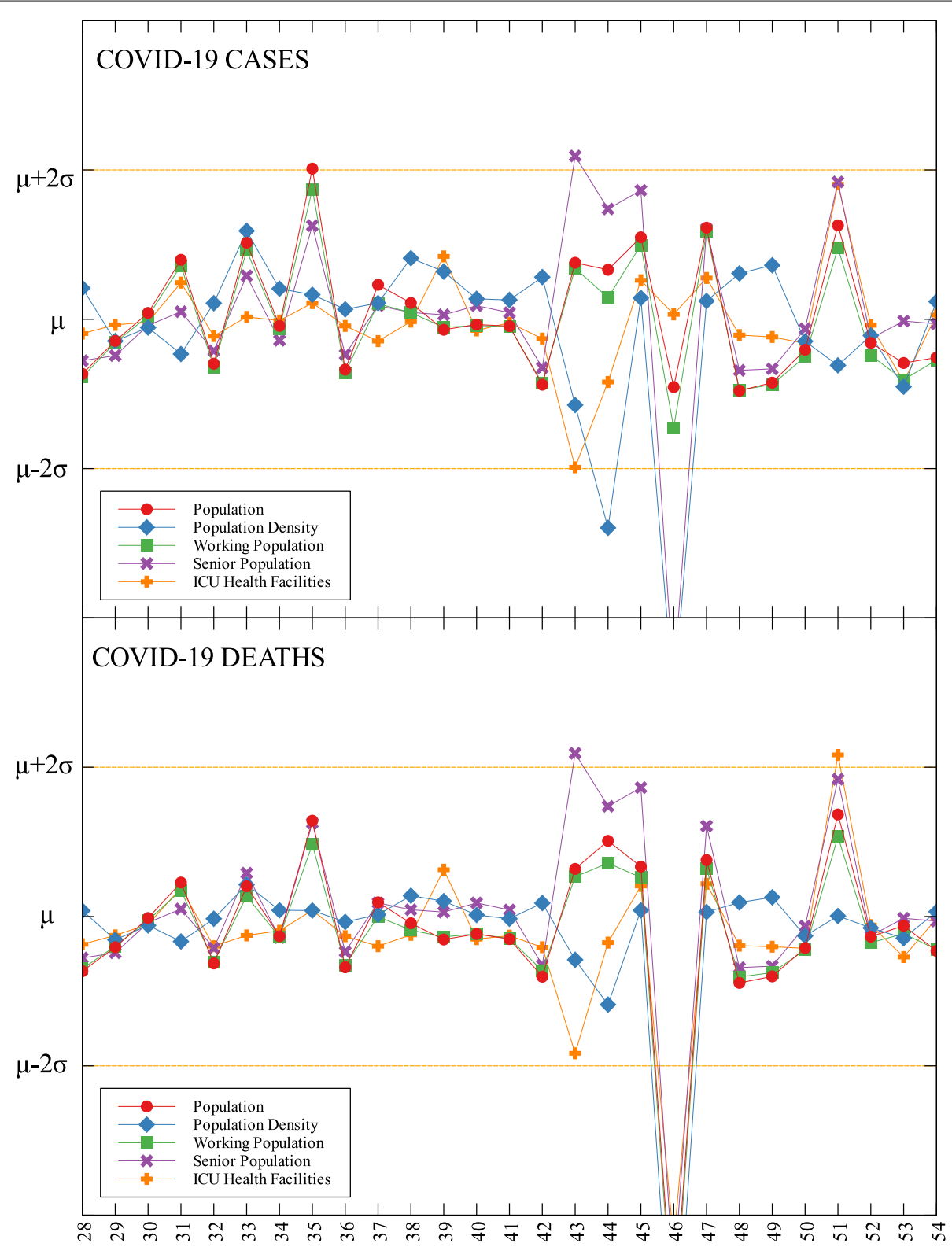

Fig. 6 Outliers among the provinces in Visayas with respect to COVID-19 cases and deaths 


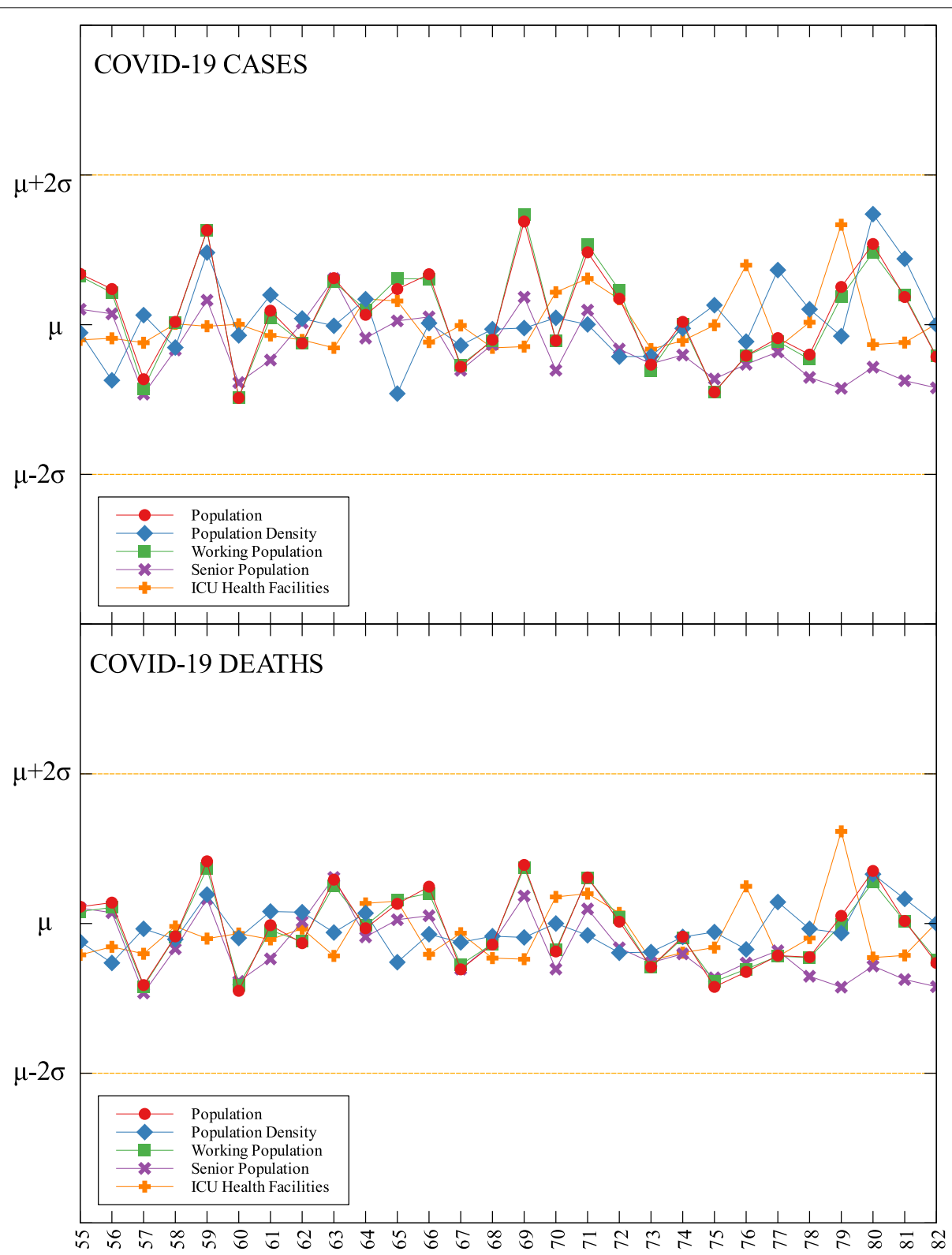

Fig. 7 Outliers among the provinces in Mindanao with respect to COVID-19 cases and deaths 


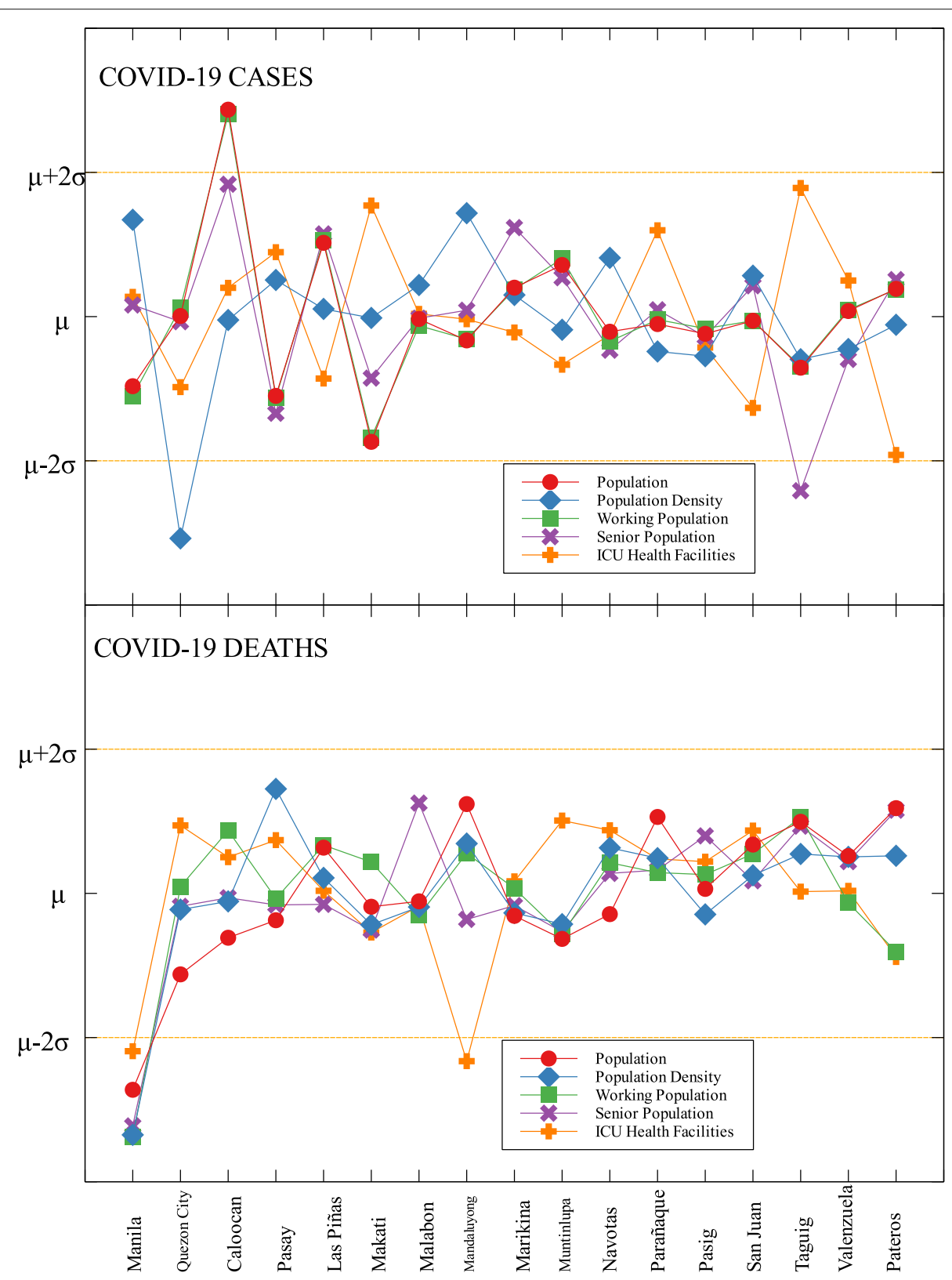

Fig. 8 Outliers in the national capital region with respect to COVID-19 cases and deaths 


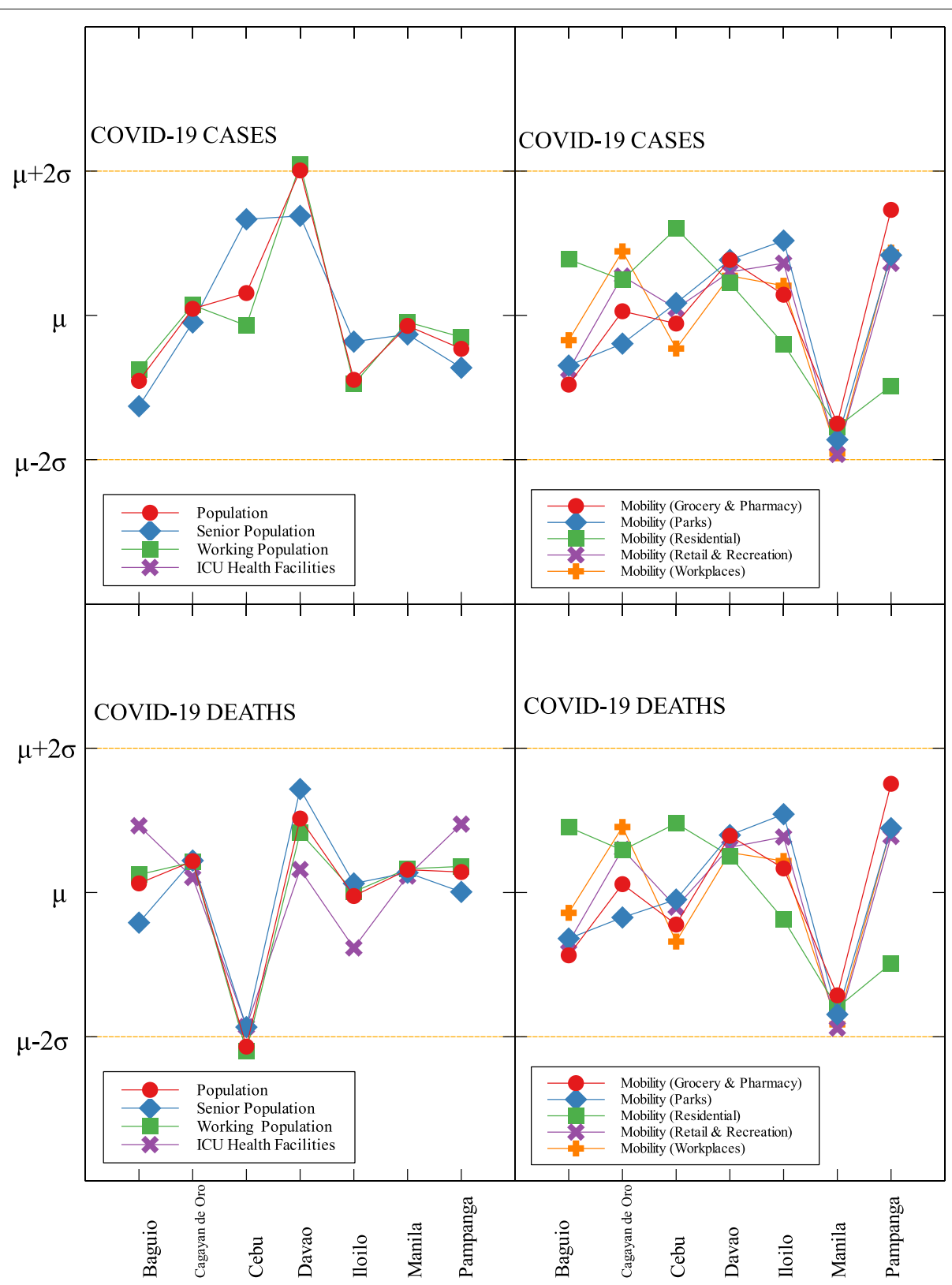

Fig. 9 Outliers among metropolitan areas in the Philippines with respect to COVID-19 cases and deaths 


\section{Acknowledgements}

JFR is supported by the Abdus Salam International Centre for Theoretical Physics Associateship Scheme.

\section{Authors' contributions}

All authors are involved in drafting the manuscript and in revising it. The author(s) read and approved the final manuscript.

\section{Funding}

This research is funded by the UP System through the UP Resilience Institute.

\section{Availability of data and materials}

The datasets used and/or analyzed during the current study are available from the corresponding author on reasonable request.

\section{Declarations}

\section{Ethics approval and consent to participate}

Not applicable. We used secondary data. These are from the public database of the Philippine Department of Health (https://www.doh.gov.ph/ covid19tracker) and Philippine Statistics Authority Census (https://psa.gov.ph)

\section{Consent for publication}

Not applicable.

\section{Competing interests}

The authors declare that they have no competing interests.

\section{Author details}

${ }^{1}$ Institute of Mathematical Sciences and Physics, University of the Philippines Los Baños, Laguna, Philippines. ${ }^{2}$ University of the Philippines Resilience Institute, University of the Philippines, Quezon City, Philippines. ${ }^{3}$ Faculty of Education, University of the Philippines Open University, Laguna, Philippines.

Received: 19 April 2021 Accepted: 30 August 2021

Published online: 21 September 2021

\section{References}

1. Li Q, Guan X, Wu P, Wang X, Zhou L, Tong Y, Ren R, Leung KSM, Lau EHY, Wong JY, Xing X, Xiang N, Wu Y, Li C, Chen Q, Li D, Liu T, Zhao J, Liu M, Tu W, Chen C, Jin L, Yang R, Wang Q, Zhou S, Wang R, Liu H, Luo Y, Liu Y, Shao G, Li H, Tao Z, Yang Y, Deng Z, Liu B, Ma Z, Zhang Y, Shi G, Lam TTY, Wu JT, Gao GF, Phil D, Cowling BJ, Yang B, Leung GM, Feng Z. Early transmission dynamics in Wuhan, China, of novel coronavirus-infected pneumonia. N Engl J Med. 2020;382(13):1199-207.

2. Hsiang S, Allen D, Annan-Phan S, Bell K, Bolliger I, Chong T, Druckenmiller H, Huang LY, Hultgren A, Krasovich E, Lau P, Lee J, RolfE, Tseng J, Wu T. The effect of large-scale anti-contagion policies on the covid-19 pandemic. Nature. 2020;584:262-67.

3. Anderson R, Heesterbeek JAP, Klinkenberg D, Hollingsworth T. Comment how will country-based mitigation measures influence the course of the covid-19 epidemic? Lancet. 2020;395:. https://doi.org/10. 1016/S0140-6736(20)30567-5.

4. Buhat CA, Torres M, Olave Y, Gavina MK, Felix E, Gamilla G, Verano KV, Babierra A, Rabajante J. A mathematical model of covid-19 transmission between frontliners and the general public. Netw Model Anal Health Inform Bioinforma. 2021;10:. https://doi.org/10.1007/s13721-021-002956.

5. Ocampo L, Yamagishic K. Modeling the lockdown relaxation protocols of the philippine government in response to the covid-19 pandemic: an intuitionistic fuzzy dematel analysis. Socioecon Plann Sci. 2020;72. https://doi.org/10.1016/j.seps.2020.100911

6. Weible C, Nohrstedt D, Cairney P, Carter D, Crow D, Durnová A, Heikkila T, Ingold K, McConnell A, Stone D. Covid-19 and the policy sciences: initial reactions and perspectives. Policy Sci. 2020;53:225-41. https://doi. org/10.1007/s11077-020-09381-4.

7. Wibbens PD, Koo WW-Y, McGahan AM. Which covid policies are most effective? a bayesian analysis of covid-19 by jurisdiction. PLOS ONE. 2020. https://doi.org/10.1371/journal.pone.0244177.
8. Mintrom M, O'Connor R. The importance of policy narrative: effective government responses to covid-19. Policy Des Pract. 2020;3(3):205-27. https://doi.org/10.1080/25741292.2020.1813358.

9. Chin T, Kahn R, Li R, Chen JT, Krieger N, Buckee CO, Balsari S, Kiang MV. Us-county level variation in intersecting individual, household and community characteristics relevant to covid-19 and planning an equitable response: a cross-sectional analysis. BMJ Open. 2020;10(9):: https://doi.org/10.1136/bmjopen-2020-039886.

10. OECD. The territorial impact of COVID-19: managing the crisis across levels of government. 2020. https://www.oecd.org/coronavirus/policyresponses/the-territorial-impact-of-covid-19-managing-the-crisisacross-levels-of-government-d3e314e1/\#biblio-d1e5202. Accessed 20 Feb 2007.

11. White ER, Hébert-Dufresne L. State-level variation of initial covid-19 dynamics in the united states. PLoS ONE. 2020;15:. https://doi.org/10. 1371/journal.pone.0240648.

12. Lin S, Huang J, He Z, Zhan D. Which measures are effective in containing covid-19? - empirical research based on prevention and control cases in China. medRxiv. 2020. https://doi.org/10.1101/2020.03.28.20046110. https://www.medrxiv.org/content/early/2020/03/30/2020.03.28. 20046110.full.pdf.

13. Mei C. Policy style, consistency and the effectiveness of the policy mix in China's fight against covid-19. Policy Soc. 2020;39(3):309-25. https://doi. org/10.1080/14494035.2020.1787627. https://doi.org/10.1080/14494035.2020.1787627.

14. Dutta A, Fischer HW. The local governance of covid-19: disease prevention and social security in rural india. World Dev. 2021;138:105234. https://doi.org/10.1016/j.worlddev.2020.105234.

15. Vallejo BM, Ong RAC. Policy responses and government science advice for the covid 19 pandemic in the philippines: january to april 2020. Prog Disaster Sci. 2020;7:100115. https://doi.org/10.1016/j.pdisas.2020.100115.

16. Inter-Agency Task Force for the Management of Emerging Infectious Diseases. Omnibus guidelines on the implementation of community quarantine in the Philippines. 2020. https://doh.gov.ph/node/27640. Accessed 20 Feb 2020.

17. Roy S, Ghosh P. Factors affecting covid-19 infected and death rates inform lockdown-related policymaking. PloS ONE. 2020;15(10):0241165. https://doi.org/10.1371/journal.pone.0241165.

18. Pullano G, Valdano E, Scarpa N, Rubrichi S, Colizza V. Evaluating the effect of demographic factors, socioeconomic factors, and risk aversion on mobility during the covid-19 epidemic in france under lockdown: a population-based study. Lancet Digit Health. 2020;2(12):638-49.

19. Department of Health. COVID-19 tracker. 2020. https://doh.gov.ph/ covid19tracker. Accessed 25 Nov 2020.

20. Authority PS. Philippine population density (based on the 2015 census of population). 2020. https://psa.gov.ph/content/philippine-populationdensity-based-2015-census-population. Accessed 11 Apr 2020.

21. Google. COVID-19 community mobility report. 2020;https://www.google. com/covid19/mobility?hl=en. Accessed 25 Nov 2020:

22. Authority PS. Labor force survey. 2020. https://psa.gov.ph/statistics/ survey/labor-and-employment/labor-force-survey?fbclid= IwAR0a5GS7XtRgRmBwAcGl9wGwNhptanSBmSNVr69cm8sCVd9wVmcoKHRCdU. Accessed 11 Apr 2020.

23. Authority PS. https://psa.gov.ph/grdp/tables?fbclid= IwAR3dKvo3B5eauY7KcWQG4VXbuiCrzFHO4bf1k5Od76ccAlYXUimUlaqs94. Accessed 11 Apr 2020. 2020.

24. Peterson E. The role of population in economic growth. SAGE Open. 2017;7:215824401773609. https://doi.org/10.1177/2158244017736094.

25. Buhat CA, Duero JC, Felix E, Rabajante J, Mamplata J. Optimal allocation of covid-19 test kits among accredited testing centers in the philippines. J Healthc Inform Res. 2021;5:. https://doi.org/10.1007/s41666-020-00081-5.

26. Hamidi S, Sabouri S, Ewing R. Does density aggravate the covid-19 pandemic?: early findings and lessons for planners. J Am Plan Assoc. 2020;86:1-15. https://doi.org/10.1080/01944363.2020.1777891.

27. Philippine News Agency. Bulacan shares anti-COVID-19 best practices 2020. https://mb.com.ph/2020/08/16/bulacan-shares-anti-covid-19best-practices/. Accessed Mar 2020.

28. Buhat CA, Villanueva SK. Determining the effectiveness of practicing non-pharmaceutical interventions in improving virus control in a pandemic using agent-based modelling. Math Appl Sci Eng. 2020;1: 423-38. https://doi.org/10.5206/mase/10876. 
29. Hallare K. Cainta, Rizal suspends classes, distributes face masks over coronavirus threat. 2020. https://newsinfo.inquirer.net/1238217/caintarizal-suspends-classes-distributes-face-masks-over-coronavirus-threat. Accessed Mar 2020.

30. Relief International. Responding to COVID-19 in the Aftermath of Volcanic Eruption. 2020. https://www.ri.org/projects/responding-to-covid-19-inthe-aftermath-of-volcanic-eruption/. Accessed Mar 2020

31. Macasero R. Averting disaster: how Cebu City flattened its curve. 2020 https://www.rappler.com/newsbreak/explainers/how-cebu-cityflattened-covid-19-curve/. Accessed Mar 2020.

32. Edrada EM, Lopez EB, Villarama JB, Salva-Villarama EP, Dagoc BF, Smith C, Sayo AR, Verona JA, Trifalgar-Arches J, Lazaro J, Balinas EGM, Telan EFO, Roy L, Galon M, Florida CHN, Ukawa T, Villaneuva AMG, Saito N, Nepomuceno JR, Ariyoshi K, Carlos C, Nicolasor AD, Solante RM. First covid-19 infections in the philippines: a case report. Trop Med Health. 2020;48(30): https://doi.org/10.1186/s41182-020-00218-7.

33. Macasero R. Coronavirus-free for 6 months, Siquijor reports first 2 cases. 2020. https://www.rappler.com/nation/siquijor-coronavirus-casesaugust-2-2020. Accessed Mar 2020.

34. Davao City. Mayor Sara, disaster radio journeying with dabawenyos. 2020. https://www.davaocity.gov.ph/disaster-risk-reduction-mitigation/mayorsara-disaster-radio-journeying-with-dabawenyos. Accessed Mar 2020.

35. Davao City. Davao city free rides to serve GCQ-allowed workers. 2020. https://www.davaocity.gov.ph/transportation-planning-trafficmanagement/davao-city-free-rides-to-serve-gcq-allowed-workers/. Accessed Mar 2020.

\section{Publisher's Note}

Springer Nature remains neutral with regard to jurisdictional claims in published maps and institutional affiliations.

Ready to submit your research? Choose BMC and benefit from:

- fast, convenient online submission

- thorough peer review by experienced researchers in your field

- rapid publication on acceptance

- support for research data, including large and complex data types

- gold Open Access which fosters wider collaboration and increased citations

- maximum visibility for your research: over $100 \mathrm{M}$ website views per year

At BMC, research is always in progress.

Learn more biomedcentral.com/submissions 